\title{
Dilated Cardiomyopathy in Transgenic Mice Expressing a Dominant-Negative CREB Transcription Factor in the Heart
}

\author{
Richard C. Fentzke, Claudia E. Korcarz, Roberto M. Lang, Hua Lin, and Jeffrey M. Leiden
}

Department of Medicine, University of Chicago, Chicago, Illinois 60637

\begin{abstract}
Idiopathic-dilated cardiomyopathy (IDC) is a common primary myocardial disease of unknown etiology characterized by progressive biventricular failure, cardiac dilatation, and premature mortality. Here we show that transgenic mice expressing a dominant-negative form of the CREB transcription factor $\left(\mathrm{CREB}_{\mathrm{A} 133}\right)$ under the control of the cardiac myocyte-specific $\alpha$-MHC promoter develop dilated cardiomyopathy that closely resembles many of the anatomical, physiological, and clinical features of human IDC. Between 2 and 20 wk of age, these mice develop four chamber cardiac dilatation, decreased systolic and diastolic left ventricular function, and attenuated contractile responses to the $\beta$-adrenergic agonist, isoproterenol. Histologically, the $\mathrm{CREB}_{\mathrm{A} 133}$ hearts demonstrated both atrophic and hypertrophied fibers as well as significant interstitial fibrosis. These anatomical and hemodynamic changes were associated with hepatic congestion and peripheral edema, intracardiac thrombi, and premature mortality. Taken together, these results implicate CREB as an important regulator of cardiac myocyte function and provide a genetic model of dilated cardiomyopathy which should facilitate studies of both the pathogenesis and therapy of this clinically important disorder. (J. Clin. Invest. 1998. 101:2415-2426.) Key words: cardiovascular models $\bullet$ congestive cardiomyopathy $\bullet$ DNA-binding protein - cAMP responsive - gene expression regulation • $\beta$-adrenergic receptors
\end{abstract}

\section{Introduction}

Congestive heart failure $(\mathrm{CHF})^{1}$ is a leading cause of cardiovascular morbidity and mortality affecting more than four million Americans and representing the most common reason for hospitalization of patients over the age of $65(1,2)$. Idiopathic dilated cardiomyopathy (IDC), a primary myocardial disease

Address correspondence to Jeffrey M. Leiden, Room B608 MC6080, University of Chicago, 5841 S. Maryland Avenue, Chicago, IL 60637. Phone: 773-702-1919; FAX: 773-702-1385; E-mail: jleiden@medicine. bsd.uchicago.edu

Received for publication 19 December 1997 and accepted in revised form 12 March 1998.

1. Abbreviations used in this paper: CBP, CREB-binding protein; $\mathrm{CHF}$, congestive heart failure; EMSA, electrophoretic mobility shift assay; IDC, idiopathic-dilated cardiomyopathy; LV, left ventricle; $\alpha$-MHC, $\alpha$-myosin heavy chain.

J. Clin. Invest.

(C) The American Society for Clinical Investigation, Inc. 0021-9738/98/06/2415/12 \$2.00

Volume 101, Number 11, June 1998, 2415-2426

http://www.jci.org of unknown etiology characterized by ventricular dilatation and depressed myocardial contractility is an important cause of CHF with an estimated prevalence of 36 cases/100,000 (37). Relatively little is known about the molecular mechanisms underlying the pathogenesis of IDC. Progress in this area has been limited by the lack of animal models that closely resemble the anatomical and clinical features of the human disease.

CREB is a $43-\mathrm{kD}$ basic leucine zipper (bZip) transcription factor that binds to the octanucleotide sequence, TGANNTCA both as a homodimer and as a heterodimer in association with other members of the CREB/ATF and AP1 families (8-12). CREB plays a critical role in regulating gene expression in response to a variety of extracellular signals including nerve growth factor in neuronal cells (13) and antigen receptor cross-linking in T lymphocytes (14). The transcriptional activity of CREB is positively regulated by phosphorylation of a critical Ser residue $\left(\operatorname{Ser}_{133}\right)$ located in the kinase-inducible domain of protein $(15,16)$. In the unphosphorylated state, CREB can bind to DNA but cannot activate transcription (16). Phosphorylation of CREB on $\operatorname{Ser}_{133}$ facilitates its interaction with the 265-kD CREB-binding protein (CBP) which in turn is able to interact with and activate the basal transcription complex (17-19). CREB phosphorylation and activation can be mediated by a variety of intracellular signaling pathways including (i) protein kinase $\mathrm{A}$ in response to elevations in intracellular cAMP (16), (ii) calmodulin kinases in response to elevations in intracellular calcium (20), and (iii) RSK2 in response to activation of a ras-dependent pathway (21). The importance of $\mathrm{Ser}_{133}$ phosphorylation for CREB transcriptional activity is underscored by the finding that a mutant CREB molecule, $\mathrm{CREB}_{\mathrm{A} 133}$ containing a $\mathrm{Ser}_{133}$ to Ala substitution functions as a potent dominant negative repressor of CREB-dependent gene expression both in vitro and in vivo (22-24).

Previous studies have provided evidence to suggest that CREB might be an important regulator of cardiac myocyte gene expression. The Ser $_{133}$-phosphorylated and transcriptionally active form of CREB is present in chicken (25), rat (26), and human cardiac myocytes (27). Moreover, G-protein coupled receptors such as the $\beta$-adrenergic receptors are important regulators of the contractile state of cardiac myocytes (28, 29). Such receptors mediate their effects by altering intracellular levels of cAMP, which, in turn, is an important regulator of CREB activity (16). In the rat, CREB mRNA levels have been reported to be reduced after chronic stimulation with the $\beta$-adrenergic agonist, isoproterenol (27), an experimental situation that mimics the chronic hyperadrenergic state that is thought to play a role in the progression of CHF (30-32). To test the role of CREB in regulating cardiac function in vivo, we produced $\mathrm{CREB}_{\mathrm{A} 133}$ transgenic mice that express a dominantnegative mutant form of CREB ( $\mathrm{Ser}_{133}$ to Ala) under the control of the cardiac myocyte-specific $\alpha$-MHC promoter. Between 2 and 20 wk of age, these mice developed severe and progressive dilated cardiomyopathy that closely resembled both the anatomical and physiological features of the human disorder. They displayed cardiac dilatation, sigificantly re- 
duced systolic and diastolic left ventricular function, hepatic congestion, peripheral edema, and intracardiac thrombi. Moreover, like patients with IDC, the $\mathrm{CREB}_{\mathrm{A} 133}$ mice died prematurely. These results identify CREB as a novel transcriptional regulator of cardiac myocyte function and provide a useful genetic model for studies of the pathophysiological mechanism(s) and treatment of human dilated cardiomyopathy.

\section{Methods}

Generation of transgenic mice. The $\alpha-\mathrm{MHC} \mathrm{CREB}_{\mathrm{A} 133}$ transgene contains the human delta CREB cDNA (along with a 5' influenza hemagglutinin [HA] epitope tag) with a $\mathrm{Ser}_{133}$ to Ala mutation as described previously (24) cloned into NotI/SalI digested pMHC, poly A vector $(28,29,33-36)$. This vector contains a $5.8-\mathrm{kb}$ BamHI/MaeIII fragment of the murine $\alpha$-myosin heavy chain $(\alpha-\mathrm{MHC})$ gene which includes the promoter and exons 1-3 from the $5^{\prime}$ untranslated region of the gene as well as an SV40 polyadenylation site (bp 2,500 to 2,700 of the SV40 genome). The transgene was linearized by digestion with HindIII and injected into the male pronucleus of fertilized single-cell $\mathrm{CD} 1$ embryos to produce the $\mathrm{CREB}_{\mathrm{A} 133}$ transgenic mice. Transgenic founders were identified by Southern blot analysis of tail DNA. BamHI-digested genomic DNA was transferred to nitrocelluose membranes, and hybridized to a 442-bp radiolabeled XbaI/NotI fragment containing exons 2 and 3 from the $5^{\prime}$ untranslated region of the murine $\alpha-\mathrm{MHC}$ gene. This probe detects both the endogenous $\alpha-\mathrm{MHC}$ gene and the transgene. All animal experimentation was performed in accordance with National Institutes of Health guidelines, and protocols were approved by the Animal Care and Use Committee of the University of Chicago.

Northern blot analysis. Total RNA was purified from mouse tissues using the TRIzol Reagent (Life Technologies, Gaithersburg, MD). mRNA was purified from $250 \mu \mathrm{g}$ of total RNA using the Fast Track 2.0 kit (Invitrogen, San Diego, CA) in accordance with the manufacturer's instructions. $10 \mu \mathrm{g}$ of total RNA or $1 \mu \mathrm{g}$ of mRNA was electrophoresed in 1.2\% denaturing (formaldehyde) agarose gels and blotted onto Nytran membranes (Schleicher \& Schuell, Keene, $\mathrm{NH})$. The following radiolabeled probes were hybridized at $42^{\circ} \mathrm{C}$ in a standard hybridization solution $(50 \%$ deionized formamide, $3 \times$ SSC, $50 \mathrm{mM}$ Hepes pH 7.0, $5 \times$ Denhardt's solution, $5 \%$ dextran sulfate, $0.1 \%$ SDS, $300 \mu \mathrm{g} / \mathrm{ml}$ denatured salmon sperm DNA): a 520-bp KpnI/BstXI fragment (bp 143-663) of the human CREB cDNA, a 363-bp cDNA fragment (bp 823-1185) obtained from the 3' UTR of aldolase A, a 257-bp cDNA fragment (bp 421-678) from the 3' UTR of ANF, and a single stranded end-labeled oligonucleotide probe $\left(5^{\prime}\right.$ GCTTTATTCTGCTTCCACCTAAAGGGCTGTTGCAAAGGCTCCAGGTCTGAGGGCTTC 3') from the 3' UTR of the $\beta$-MHC gene. Blots were washed twice for $15 \mathrm{~min}$ at room temperature in $2 \times$ $\mathrm{SSC} / 0.1 \% \mathrm{SDS}$, and once for $30 \mathrm{~min}$ at $55^{\circ} \mathrm{C}$ in $0.1 \times \mathrm{SSC} / 0.1 \% \mathrm{SDS}$.

Western blot analysis. $50 \mu \mathrm{g}$ of nuclear extract prepared as described below (see electrophoretic mobility shift assays) was subjected to immunoblot analysis using the commercially available PhosphoPlus CREB kit (New England Biolabs, Beverly, MA) according to the manufacturer's instructions.

Histologic analysis. Mouse tissues were fixed in $4 \%$ paraformaldehyde overnight at $4^{\circ} \mathrm{C}$, embedded in paraffin and 4-mm sections were cut on a Jung Histocut 820 microtome. Sections were stained with hematoxylin and eosin or Masson's trichrome stain. Photomicrographs were obtained using Nikon SMZ-U (Melville, NY) or Zeiss Axiophot (Thornwood, NY) microscopes.

DNA laddering assay. Genomic DNA was purified from freshly isolated whole hearts, precipitated in ethanol overnight at $4^{\circ} \mathrm{C}$, and collected by centrifugation at $27,000 \mathrm{~g}$ for $20 \mathrm{~min}$ to ensure recovery of small fragments of DNA. Total DNA was radiolabeled with ${ }^{32} \mathrm{P}-$ dCTP and dGTP (800 Ci/mmol) (Amersham Corp., Arlington Heights, IL) using the Klenow fragment of DNA polymerase I. Radiolabeled DNA was fractionated by electrophoresis in $2 \%$ agarose gels, blotted to a Zeta-Probe membranes (BioRad, Hercules, CA) and autoradiographed.

Echocardiographic analysis. Anesthesia was induced with 2-5\% halothane, 95-98\% $\mathrm{O}_{2}$ (Ohmeda Fluotec 3; Matrx Medical, Orchard Park, NY) and animals were intubated with an 18 gauge angiocatheter. Anesthesia was maintained by ventilation (SAR 830; CWE Inc., Ardmore, PA) with $1 \%$ halothane, $99 \% \mathrm{O}_{2}$ at $130-150$ breaths per minute and a tidal volume of $0.8-1.2 \mathrm{ml} / \mathrm{min}$. The central aorta was catheterized via the right carotid artery with a 1.8 French micromanometer catheter (Millar, Houston, TX). A venous catheter (PE-10 tubing) was placed in the jugular vein. The animals were transferred to a heated water bed and ECG electrodes were placed underneath the paws. High fidelity central aortic pressures were obtained using a 1.8F Millar Mikro-Tip catheter pressure transducer (SPR-612; Millar, Houston, TX) introduced into the right carotid artery and advanced to the level of the ascending aorta. Analog signals from the pressure transducer and ECG were digitized using an analog to digital converter (AD3100; Real Time Devices, State College, PA). Digital files were recorded and analyzed with commercially available software (Atlantis and Pegasus software, Lakeshore Technologies, Chicago, IL). Simultaneous two-dimensionally targeted M-mode echocardiographic recordings of the left ventricle were obtained at the level of the papillary muscles from a parasternal window using a HewlettPackard (Andover, MA) Sonos 5500 and a pediatric broad-band 12 $\mathrm{MHz}$ transducer. Isoproterenol (1 ng/min) was administered into the jugular vein at a constant rate using a syringe pump. Measurements were recorded $7 \mathrm{~min}$ after the start of the infusion. One nontransgenic animal could not be catheterized for technical reasons and four transgenic animals died after the induction of anesthesia. These animals were not included in the analysis. Statistically significant differences between groups were determined using the unpaired Student's $t$ test. Shortening fraction was calculated as (EDD-ESD/ EDD) $\times 100$.

Cardiac catheterization. Mice were anesthetized with $100 \mathrm{mg} / \mathrm{kg}$ ketamine, $5 \mathrm{mg} / \mathrm{kg}$ xylazine, and $1 \mathrm{mg} / \mathrm{kg}$ buprenorphine, intubated with an 18 gauge angiocatheter, and ventilated at $130-150$ breaths per minute with a $0.8-1.2 \mathrm{ml}$ tidal volume using $100 \% \mathrm{O}_{2}$ as described above. The left ventricle was catheterized via the right carotid artery using a 1.8 French micromanometer catheter (SPR-612; Millar). Baseline central aortic pressures were recorded before advancing the catheter into the left ventricle. 10-s bursts of pressure and ECG tracings were recorded and analyzed as described above. Isoproterenol $40 \mathrm{ng} / \mathrm{kg}$ (in phosphate buffered saline) was administered directly into the jugular vein. Recordings were taken 20,30 , and $40 \mathrm{~s}$ after administration of isoproterenol and $5 \mathrm{~s}$ of data representing the maximal stimulation were used to calculate isoproterenol responses. Two nontransgenic animals could not be catheterized for technical reasons and four transgenic mice died after the induction of anesthesia. These mice were not included in the analysis. Statistically significant differences between groups were determined using the unpaired Student's $t$ test.

Electrophoretic mobility shift assays. Nuclear extracts were prepared from 8-wk-old $\mathrm{CREB}_{\mathrm{A} 133}$ and wild-type hearts. Freshly isolated hearts were washed in ice cold PBS with $10 \mathrm{mM}$ EDTA. Ventricles were isolated, finely minced with a razor blade and homogenized in $5 \mathrm{ml}$ of buffer A $\left(10 \mathrm{mM}\right.$ Hepes $\mathrm{pH} 7.9,1.5 \mathrm{mM} \mathrm{MgCl}_{2}, 10 \mathrm{mM} \mathrm{KCl}$, $0.5 \mathrm{mM}$ DTT, $1.0 \mathrm{mM}$ PMSF) in a $7-\mathrm{ml}$ glass Dounce tissue grinder using piston $\mathrm{B}$. The homogenate was centrifuged at $5,640 \mathrm{~g}$ for 15 min. The pellet was resuspended in $5 \mathrm{ml}$ of buffer A, rehomogenized and recentrifuged. The second pellet was resuspended in $2 \mathrm{ml}$ of buffer B (25\% glycerol, $20 \mathrm{mM}$ Hepes $\mathrm{pH} 7.9,550 \mathrm{mM} \mathrm{NaCl}, 1.5 \mathrm{mM}$ $\mathrm{MgCl}_{2}, 0.2 \mathrm{mM}$ EDTA, $0.5 \mathrm{mM}$ DTT, $1.0 \mathrm{mM}$ PMSF, $1 \mathrm{mM}$ benzamidine, $5 \mathrm{mg} / \mathrm{ml}$ aprotinin, $1 \mathrm{mg} / \mathrm{ml}$ antipain, $1 \mathrm{mg} / \mathrm{ml}$ pepstatin $\mathrm{A}, 1 \mathrm{mg} /$ $\mathrm{ml}$ leupeptin, $20 \mathrm{mM}$ chymostatin) and homogenized using piston A. The homogenate was centrifuged at $14,000 \mathrm{rpm}$ in a microfuge, and the supernatant was dialyzed for $4 \mathrm{~h}$ against $20 \%$ glycerol, $15 \mathrm{mM}$ Hepes pH 7.9, $40 \mathrm{mM} \mathrm{KCl}, 1 \mathrm{mM}$ EDTA, $0.5 \mathrm{mM}$ DTT, $1.0 \mathrm{mM}$ PMSF. All procedures were performed on ice or at $4^{\circ} \mathrm{C}$. Protein con- 
centrations were determined using the BioRad Protein Assay. Extracts were stored in aliquots at $-70^{\circ} \mathrm{C}$. For electrophoretic mobility shift assays, $11 \mu \mathrm{g}$ of nuclear extract was mixed with $20,000 \mathrm{cpm}$ of radiolabeled oligonucleotide probe (see below) in $10 \mathrm{mM}$ Tris, $\mathrm{pH} 7.5$, $100 \mathrm{mM} \mathrm{NaCl}, 4 \%$ glycerol, $1 \mathrm{mM}$ EDTA, $5 \mathrm{mM}$ DTT, $100 \mu \mathrm{g} / \mathrm{ml}$ BSA, and $67 \mu \mathrm{g} / \mathrm{ml}$ poly dI:dC at room temperature for $20 \mathrm{~min}$. Complexes were fractionated by electrophoresis in $4 \% \mathrm{~T}, 3.2 \% \mathrm{C}$ polyacrylamide gels in $1 \times$ TGE (100 mM Tris, $760 \mathrm{mM}$ glycine, $4 \mathrm{mM}$ EDTA) (100 V for $2.5 \mathrm{~h}$ at room temperature). Gels were dried and subjected to autoradiography. As a control, a binding reaction containing in vitro translated CREB protein was run in parallel on each gel. The oligonucleotide probes used in these studies were the CREB site from the somatostatin promoter (SOM) and the AP-1 site from the metallothionein promoter. As a negative control, we used an oligonucleotide with a mutation in the CREB site which prevents binding $(\mathrm{mSOM})$ :

CREB (SOM): 5' GATCGCCTCCTTGGCTGACGTCAGAGAGCTAG $3^{\prime}$

mCREB (mSOM): 5' GATCGCCTCCTTGGCTCAGCACAGAGAGCTAG 3'

AP-1 (MTT): 5' TCGACGTGACTCAGCGCGCAGCT 3'

For antibody supershift experiments $2 \mu \mathrm{l}$ of antibody were added to the binding reactions and incubated at room temperature for $20 \mathrm{~min}$. Antibodies used for these studies were anti-CREB (24H4B; Santa Cruz Biotechnology, Santa Cruz, CA), anti-HA (3F10, $0.5 \mu \mathrm{g} / \mu \mathrm{l}$, Boehringer Mannheim, Indianapolis, IN), anti-NF-кB (NF-кB p65(A)-G; Santa Cruz Biotechnology).

\section{Results}

Production and molecular characterization of $C R E B_{A 133}$ transgenic mice. To test directly the role of CREB in cardiac myocyte function, we produced transgenic mice that express a dominant-negative form of $\mathrm{CREB}\left(\mathrm{CREB}_{\mathrm{A} 133}\right)$ under the transcriptional control of the cardiac-specific $\alpha$-MHC promoter. This mutant CREB protein which contains an Ala for Ser substitution at aa 133 cannot be phosphorylated (and activated) and has been shown previously to function both in vitro and in vivo as a potent dominant-negative inhibitor of CREB-dependent transcription (22-24). Tissue-specific expression of this molecule in transgenic mice has been used to elucidate the role of CREB in the development and function of both anterior pituitary cells (24) and T cells (14). The $\alpha$-MHC promoter (33, 34) has been used extensively in previous transgenic models $(28,29,35,36)$. This promoter is expressed in both embryonic and adult atrial myocytes. However, its expression in ventricular myocytes is restricted to postnatal and adult life.

Three independently derived $\mathrm{CREB}_{\mathrm{A} 133}$ founders (Tg1, $\mathrm{Tg} 2$, and $\mathrm{Tg} 3$ ) were produced containing between 15 and 50 copies, respectively, of the transgene as assessed by Southern blot analysis (Fig. $1 A$ ). Northern blot analysis demonstrated that expression of the $\mathrm{CREB}_{\mathrm{A} 133}$ transgene was restricted to the heart $\left(\right.$ Fig. $1 \mathrm{~B}$ ). Because the $\mathrm{CREB}_{\mathrm{A} 133}$ protein contained an HA epitope tag it could be distinguished from endogenous wild-type CREB on Western blots by both its increased molecular weight and by its specific immunoreactivity with an antiHA antiserum. As shown in the lower panel of Fig. $1 C$, the $\mathrm{CREB}_{\mathrm{A} 133}$ hearts contained an excess of $\mathrm{CREB}_{\mathrm{A} 133}$ as compared to wild-type endogenous CREB. Western blotting of cardiac nuclear extracts with an antiserum specific for the Ser $_{133}$-phosphorylated and transcriptionally active form of CREB (pCREB, Fig. $1 C$, top) demonstrated that wild-type hearts contained easily detectable levels of pCREB. In con-

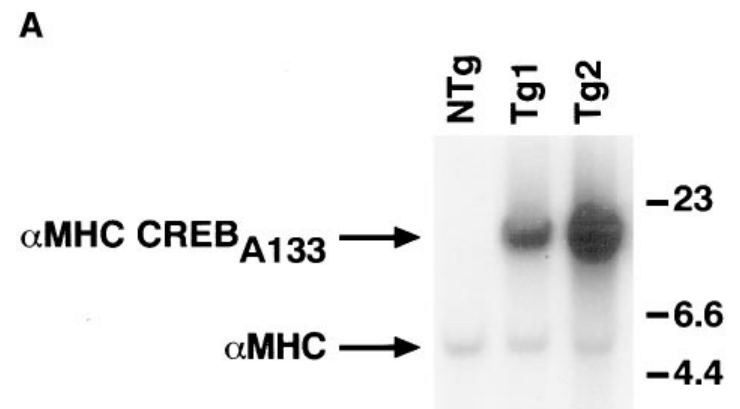

B

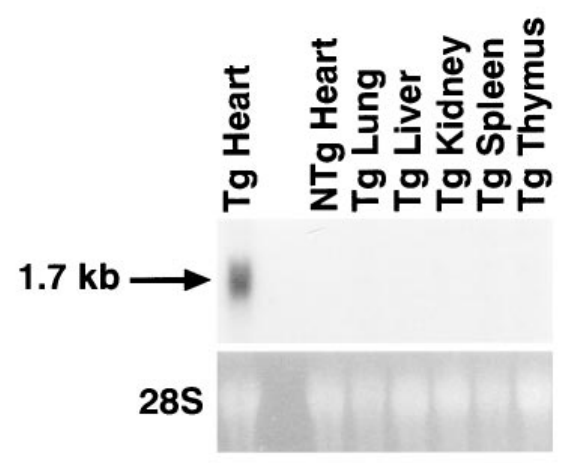

C

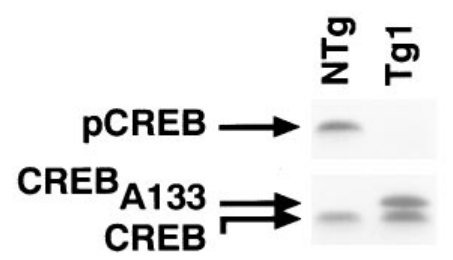

Figure 1. Molecular characterization of the $\mathrm{CREB}_{\mathrm{A} 133}$ mice. $(A)$ Southern blot analysis of tail DNA from two independently derived $\mathrm{CREB}_{\mathrm{A} 133}$ transgenic ( $T g 1$ and $\left.T g 2\right)$ mice and one nontransgenic control littermate $(N T g)$. The probe detects both the endogenous $\alpha$-MHC gene $(\alpha M H C)$ and the transgene $\left(\alpha M H C C R E B_{A 133}\right) .(B)$ Northern blot analysis of $\mathrm{CREB}_{\mathrm{A} 133}$ expression in organs from a transgenic $\mathrm{CREB}_{\mathrm{A} 133}$ mouse. The probe used in these experiments hybridizes to the human transgene mRNA but not to the endogenous mouse CREB mRNA. To ensure equal loading, gels were stained with ethidium bromide to visualize 28S RNA $(28 S)$ before transfer to nylon membranes. The size of the $\mathrm{CREB}_{\mathrm{A} 133}$ mRNA is shown to the left of the autoradiogram. $(C)$ Western blot analysis of CREB (bottom) and phospho-CREB ( $p C R E B$, top) expression in cardiac nuclear extracts from nontransgenic control $(N T g)$ and $\mathrm{CREB}_{\mathrm{A} 133}$ transgenic mice $(T g)$. Note the slower electrophoretic mobility of the transgenic $\mathrm{CREB}_{\mathrm{A} 133}$ protein due to inclusion of the $\mathrm{HA}$ epitope tag and the absence of detectable pCREB in the $\mathrm{CREB}_{\mathrm{A} 133}$ cardiac nuclear extracts. Equal protein loading was verified by equivalent intensities of nonspecific backround bands (data not shown).

trast, no transcriptionally active pCREB was detectable in the $\mathrm{CREB}_{\mathrm{A} 133}$ cardiac nuclear extracts.

Electrophoretic mobility shift assays (EMSAs) using nuclear extracts from wild-type mice demonstrated that CREB 
homodimers are the major CRE binding activity present in normal hearts (Fig. 2, lane 1). This conclusion was based on the findings that the single major band in the wild-type CRE EMSA displayed an identical electrophoretic mobility to in vitro translated CREB protein and was quantitatively supershifted by a CREB-specific antibody (Fig. 2, lane 5) but not by control antibodies to the hemagluttinin epitope tag $(\alpha-\mathrm{HA})$ or the NF-кB transcription factor (Fig. 2, lanes 7 and 9). Nuclear extracts from the $\mathrm{CREB}_{\mathrm{A} 133}$ hearts contained approximately two- to threefold more CREB binding activity than extracts from the wild-type hearts (Fig. 2, compare lanes 1 and 2). This increased CREB binding activity which displayed an identical electrophoretic mobility to CREB homodimers was due to expression of the $\mathrm{CREB}_{\mathrm{A} 133}$ protein because $\sim 2 / 3$ of the binding activity in these extracts could be supershifted by the $\alpha-\mathrm{HA}$ antibody which is specific for the HA-tagged $\mathrm{CREB}_{\mathrm{A} 133}$ transgene protein. Because CREB has been reported to be capable of heterodimerizing with some AP1 family members $(22,23)$, we also performed EMSAs with a radiolabeled AP1 probe. Both wild-type and $\mathrm{CREB}_{\mathrm{A} 133}$ cardiac nuclear extracts contained barely detectable but equivalent levels of AP1-binding activity (data not shown). Taken together, these results demonstrated that (i) CREB homodimers are the predominant CREB binding activity in wild-type hearts, (ii) the $\mathrm{CREB}_{\mathrm{A} 133}$ mice display cardiac-specific overexpression of a dominant-

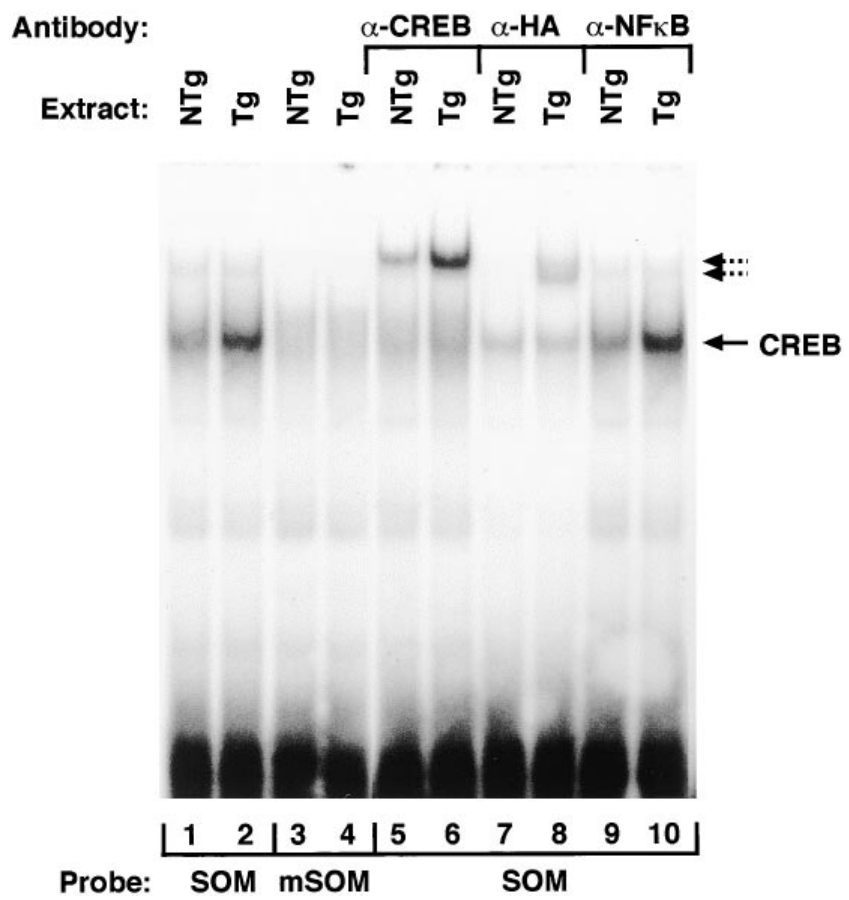

Figure 2. Electrophoretic mobility shift analysis of CRE-binding activities in $\mathrm{CREB}_{\mathrm{A} 133}$ cardiac nuclear extracts. EMSAs were performed with radiolabled probes containing intact (SOM) or mutant ( $m S O M$ ) CREB sites from the somatostatin promoter and nuclear extracts from $\mathrm{CREB}_{\mathrm{A} 133}(T g)$ or wild-type littermate control $(N T g)$ hearts. For supershift experiments, the indicated antibodies against CREB, HA, or NF- $\mathrm{kB}$ were added to the binding reactions. The solid arrow shows the electrophoretic mobility of in vitro translated CREB homodimers. The dotted arrows indicate the positions of the antibody supershifted complexes. negative form of CREB, (iii) overexpression of $\mathrm{CREB}_{\mathrm{A} 133}$ in the heart results in undetectable levels of transcriptionally active nuclear pCREB, and (iv) the $\mathrm{CREB}_{\mathrm{A} 133}$ protein present in cardiac extracts from $\mathrm{CREB}_{\mathrm{A} 133}$ transgenic mice binds efficiently to CRE but not to AP1 sites.

Pathological evidence of dilated cardiomyopathy in the $C R E B_{A 133}$ mice. Detailed pathological, echocardiographic, and hemodynamic analyses were performed on mice derived from the first $\mathrm{CREB}_{\mathrm{A} 133}$ founder ( $\left.\mathrm{Tg} 1\right)$ and confirmed by histological analyses and cardiac catheterization in a second founder line (Tg2). The $\mathrm{CREB}_{\mathrm{A} 133}$ mice demonstrated both gross and histological evidence of dilated cardiomyopathy. At necropsy, the hearts from adult $\mathrm{CREB}_{\mathrm{A} 133}$ animals displayed marked four chamber dilatation (Fig. 3, $A-C$ ) and, in many animals, both the ventricles and the atria were found to contain thrombi in various states of organization (data not shown). Cross-sections through the ventricles demonstrated biventricular enlargement without significant increases in wall thickness (Fig. 3, $B$ and $C$ ). Consistent with this finding, the weights of both the $\mathrm{CREB}_{\mathrm{A} 133}$ hearts and the $\mathrm{CREB}_{\mathrm{A} 133}$ left ventricles (LV) were not significantly different from those of age matched wild-type littermates (data not shown). Histological examination revealed marked heterogeneity in myocyte size in the $\mathrm{CREB}_{\mathrm{A} 133}$ hearts as compared to control hearts, with some myocytes demonstrating hypertrophy and others appearing atrophied (Fig. 3, $D$ and $E$ ). In addition, many $\mathrm{CREB}_{\mathrm{A} 133}$ cardiac myocytes appeared vacuolated (Fig. $3 G$ ). Staining with Masson's trichrome stain for collagen demonstrated significant interstitial fibrosis in the $\mathrm{CREB}_{\mathrm{A} 133}$ ventricles compared with ventricles from nontransgenic control littermates (Fig. 3, $F$ and $G)$. These histological changes were seen in the $\mathrm{CREB}_{\mathrm{A} 133}$ hearts as early as $4 \mathrm{wk}$ of age and were seen in all mice by $8 \mathrm{wk}$ of age. Of note, significant inflammatory cell infiltrates were not observed in the $\mathrm{CREB}_{\mathrm{A} 133}$ hearts (Fig. 3, D-G).

Echocardiographic assessment of left ventricular dimensions and function in the $C R E B_{A 133}$ mice. Recent technological advances have made possible the echocardiographic assessment of murine cardiac structure and function (37-41). Accordingly, we assessed both the LV dimensions and systolic function of the $\mathrm{CREB}_{\mathrm{A} 133}$ mice using two-dimensionally targeted M-mode echocardiography acquired both at baseline and following stimulation with the $\beta$-adrenergic agonist, isoproterenol (Fig. 4). In keeping with the pathological findings of left ventricular dilatation shown in Fig. 3, baseline echocardiographic analyses demonstrated 33 and 18\% increases in left ventricular end systolic and end diastolic dimensions, respectively, in the $\mathrm{CREB}_{\mathrm{A} 133}$ mice as compared with the nontransgenic littermate controls $(P<0.005)$ (Fig. $4 B)$. Shortening fraction, the percent fractional change in LV cavity size during ventricular systole is an echocardiographic index of left ventricular systolic function. A comparison of the baseline LV shortening fractions of the $\mathrm{CREB}_{\mathrm{A} 133}$ animals with those of nontransgenic control littermates demonstrated $35 \%$ decreases in shortening fraction in the $\mathrm{CREB}_{\mathrm{A} 133}$ mice $(P<0.005)$ (Fig. $\left.4 C\right)$. Increases in $\mathrm{LV}$ contractility in response to $\beta$-adrenergic stimulation represent one index of contractile reserve. Therefore, we also compared the LV-shortening fractions of the $\mathrm{CREB}_{\mathrm{A} 133}$ and control mice after intravenous infusion of isoproterenol (Fig. 4 $C)$. The nontransgenic control animals demonstrated a $54 \%$ increase in shortening fraction in response to treatment with isoproterenol. In contrast, the $\mathrm{CREB}_{\mathrm{A} 133}$ mice demonstrated a significantly reduced $(34 \%)$ enhancement in shortening frac- 


\section{NTg}
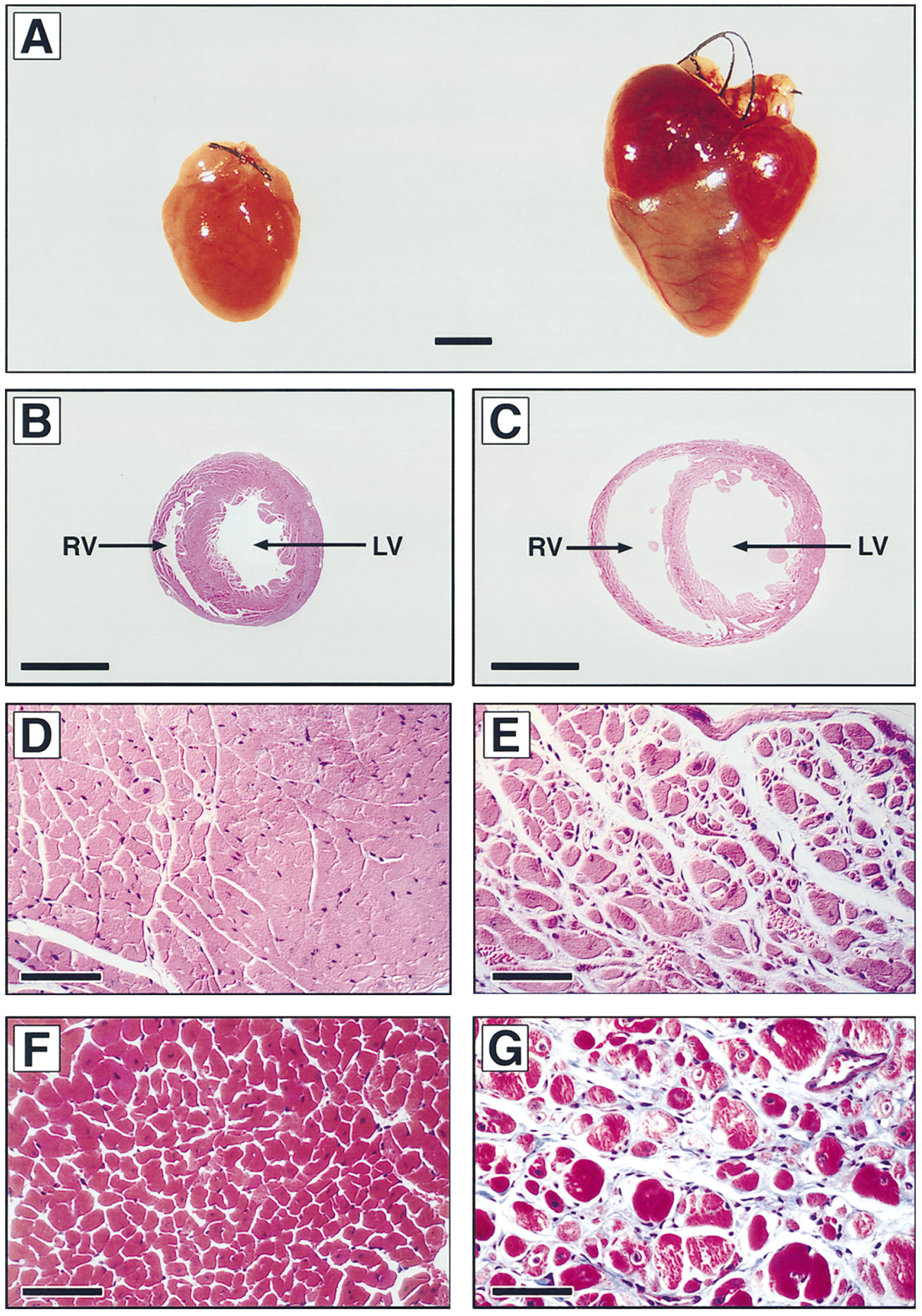

Figure 3. Pathological analyses of the $\mathrm{CREB}_{\mathrm{A} 133}$ hearts. $(A)$ Gross pathology of freshly isolated hearts from $\mathrm{CREB}_{\mathrm{A} 133}(T g)$ and nontransgenic control $(\mathrm{NTg})$ animals. Note both the atrial and ventricular dilatation of the $\mathrm{CREB}_{\mathrm{A} 133}$ heart. Size bar, 2.5 mm. $(B-G)$ : Histological sections of hearts from $\mathrm{CREB}_{\mathrm{A} 133}$ mice $(C, E$, and $G)$ and control littermates $(B, D$, and $F)$. Hearts were fixed in $4 \%$ paraformaldehyde, sectioned at the level of the papillary muscles, and stained with hematoxylin and eosin. $(B)$ and $(C)$ show low power photomicrographs; size bar, $2.5 \mathrm{~mm}$. $(D)$ and $(E)$ show higher power photomicrographs; size bar, $60 \mu \mathrm{m}$. Both the left $(L V)$ and right $(R V)$ ventricles are enlarged in the CREB $_{\mathrm{A} 133}$ heart. $(F)$ and $(G)$. Photomicrographs of histological sections of hearts from $\mathrm{CREB}_{\mathrm{A} 133}$ mice $(\mathrm{Tg})$ and nontransgenic littermates $(N T g)$ stained with Masson's Trichrome stain. Note the marked heterogeneity in myocyte size, the presence of vacuolated myocytes, and the presence of interstitial fibrosis (which stains blue with Trichrome) in the $\mathrm{CREB}_{\mathrm{A} 133}$ heart. Size bar, $60 \mu \mathrm{m}$. tion after $\beta$-adrenergic stimulation $(P<0.0005)$. These experiments provided in vivo confirmation of the LV dilatation of the $\mathrm{CREB}_{\mathrm{A} 133}$ mice. They also demonstrated depressed LV systolic function at baseline and decreased contractile reserve in response to $\beta$-adrenergic stimulation in these animals.

Hemodynamic assessment of left ventricular function in the $C R E B_{A 133}$ mice. Cardiac catheterizations using a high fidelity micromanometer catheter were performed to further analyze the left ventricular function of the $\mathrm{CREB}_{\mathrm{A} 133}$ mice, both in the basal state and after stimulation with the $\beta$-adrenergic agonist, isoproterenol (Fig. 5). Adult $\mathrm{CREB}_{\mathrm{A} 133}$ mice demonstrated significantly depressed LV systolic function as assessed by the maximal first derivative of the $\mathrm{LV}$ pressure $\left(\mathrm{dP} / \mathrm{dt}_{\max }\right)$ (Fig. 5 $A)$. At baseline, $\mathrm{dP} / \mathrm{dt}_{\max }$ was $24 \%$ less in the $\mathrm{CREB}_{\mathrm{A} 133}$ mice as compared with nontransgenic control littermates $(P<0.05)$. The $\mathrm{CREB}_{\mathrm{A} 133}$ mice also displayed basal abnormalities of dia- 

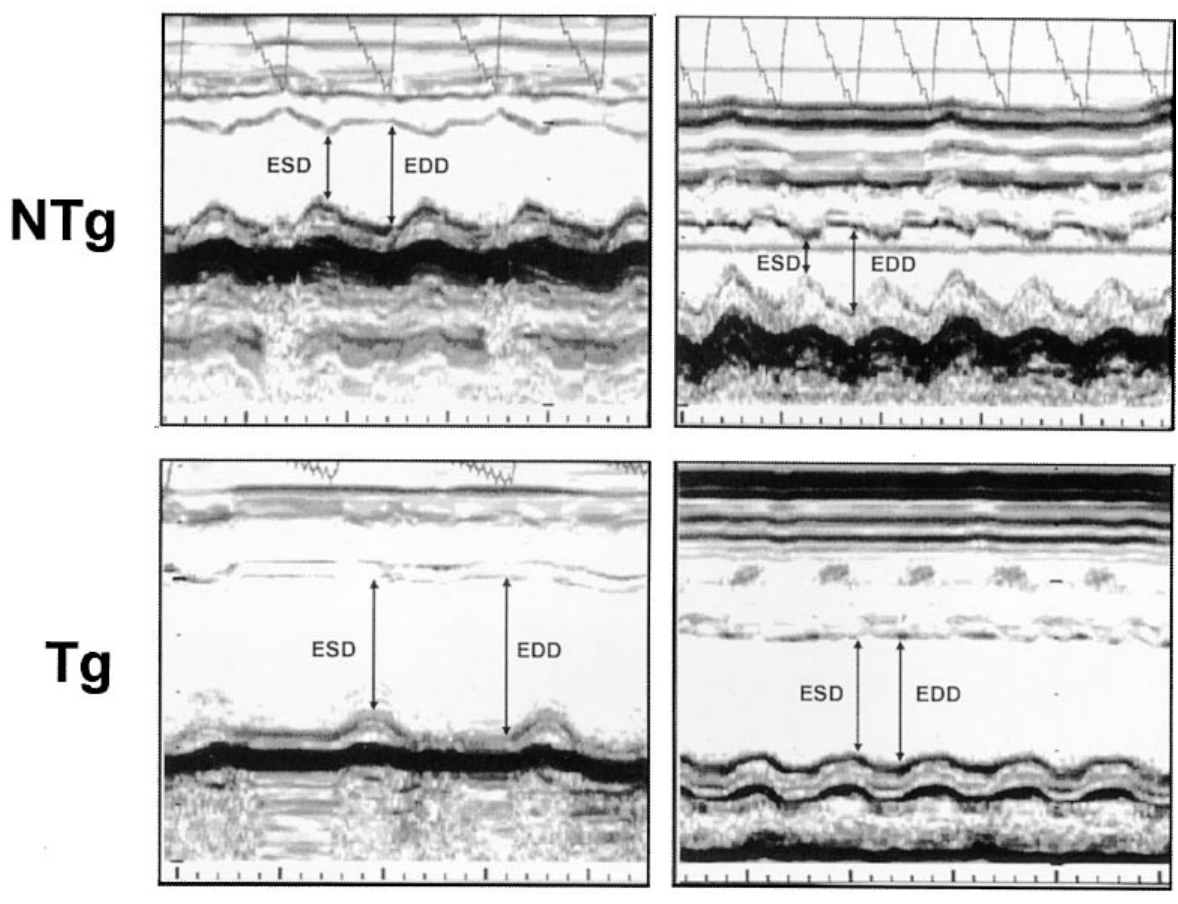

Baseline

B

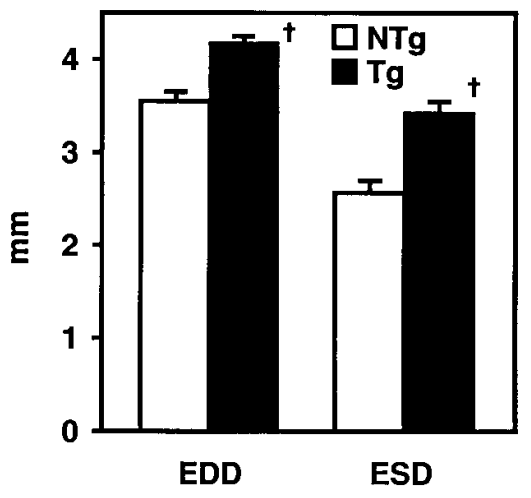

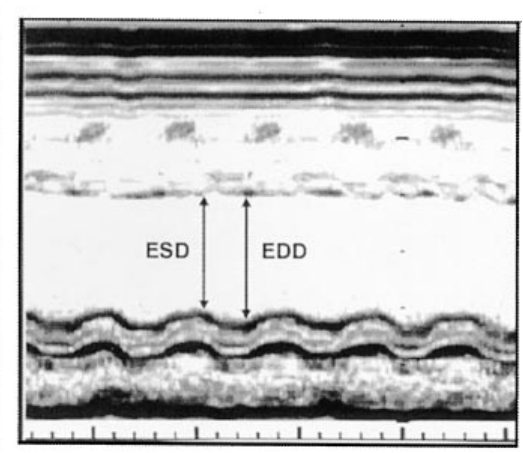

Isoproterenol

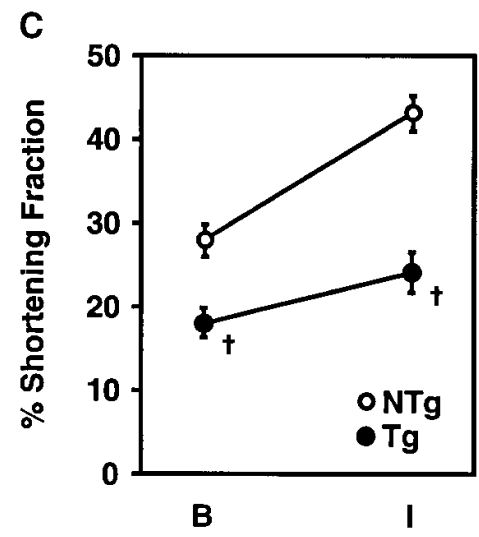

Figure 4. M-mode echocardiographic analysis of the $\mathrm{CREB}_{\mathrm{A} 133}$ mice. ( $A$ ) Two dimensionally targeted $\mathrm{M}$-mode echocardiograms were obtained at the level of the papillary muscles at baseline (left panels) and after a continuous intravenous infusion of $1 \mathrm{ng} /$ min isoproterenol (right panels). Note the increased end diastolic $(E D D)$ and endsystolic $(E S D)$ dimensions and the decreased response to isoproterenol in the CREB $_{\mathrm{A} 133}$ animals. (B) End diastolic $(E D D)$ and end systolic $(E S D)$ dimensions as determined by M-mode echocardiography in the $\mathrm{CREB}_{\mathrm{A} 133}$ mice $(T g)(n=9)$ and nontransgenic control littermates $(N T g)(n=10)$. (C) Shortening fraction at baseline $(B)$ and following a continuous intravenous infusion of $1 \mathrm{ng} / \mathrm{min}$ isoproterenol $(I)$ in the $\mathrm{CREB}_{\mathrm{A} 133}(T g)(n=9)$ and nontransgenic control littermates $(N T g)$ $(n=10)$. Note the diminished response to isoproterenol in the $\mathrm{CREB}_{\mathrm{A} 133}$ animals as compared to the NTg controls. The data in $(B)$ and $(C)$ are shown as mean \pm SEM. ${ }^{\dagger}$ Significant differences $(P<0.005)$ between the control and $\mathrm{Tg}$ groups. stolic relaxation with $35 \%$ reductions in the maximal negative derivative of $\mathrm{LV}$ pressure $\left(\mathrm{dP}^{\mathrm{d}} \mathrm{dt}_{\text {min }}\right)$ as compared with nontransgenic littermate controls $(P<0.005)$. As shown in Fig. 5, $C$ and $D$, nontransgenic control mice demonstrated significant enhancements of both $\mathrm{dP} / \mathrm{dt}_{\max }$ and $\mathrm{dP} / \mathrm{dt}_{\min }$ after stimulation with the $\beta$-adrenergic agonist, isoproterenol. In contrast, the $\mathrm{CREB}_{\mathrm{A} 133}$ mice demonstrated significantly reduced responses of both $\mathrm{dP} / \mathrm{dt}_{\max }$ and $\mathrm{dP} / \mathrm{dt}_{\min }$ after isoproterenol treatment (Fig. 5, $B$ and $C)(P<0.005$ for both values). Thus, the results of these experiments confirmed the echocardiographic findings and demonstrated abnormalities of both basal LV systolic and diastolic function as well as reduced responsiveness to $\beta$-adrenergic stimulation in the $\mathrm{CREB}_{\mathrm{A} 133}$ mice.

We also monitored central aortic blood pressures in the $\mathrm{CREB}_{\mathrm{A} 133}$ mice. The $\mathrm{CREB}_{\mathrm{A} 133}$ mice demonstrated significant reductions in systolic, diastolic, and mean arterial blood pres- sures as compared to nontransgenic control littermates $(P<$ 0.05) (Fig. $5 \mathrm{D}$ ). In humans with IDC, reductions in blood pressure are typically seen only in association with marked LV dysfunction. Therefore, our findings of reduced blood pressure in the $\mathrm{CREB}_{\mathrm{A} 133}$ mice likely reflected the severity of the $\mathrm{CHF}$ in these animals. Despite the observed reductions in blood pressure, electrocardiographic monitoring of the $\mathrm{CREB}_{\mathrm{A} 133}$ mice did not reveal significant elevations in heart rate. This lack of tachycardia may reflect the bradycardic effects of the anesthetic agents used in these experiments and/or the relatively rapid basal heart rates of mice (400-600 beats per min).

Molecular assessment of cardiomyocyte gene expression in the $C R E B_{A 133}$ mice. Previous studies have demonstrated that the myocardial response to increased workloads includes the transcriptional activation of several embryonic and contractile protein genes. These include the atrial natriuretic factor 
A
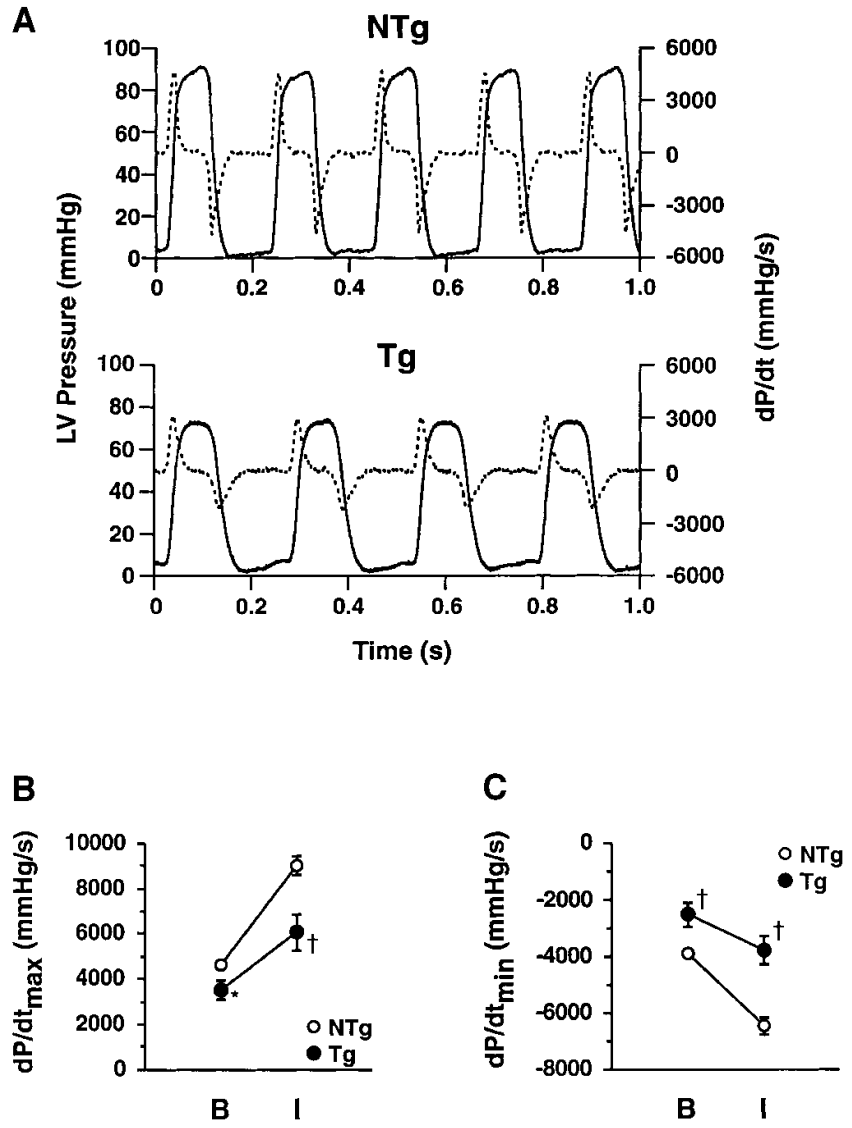

D

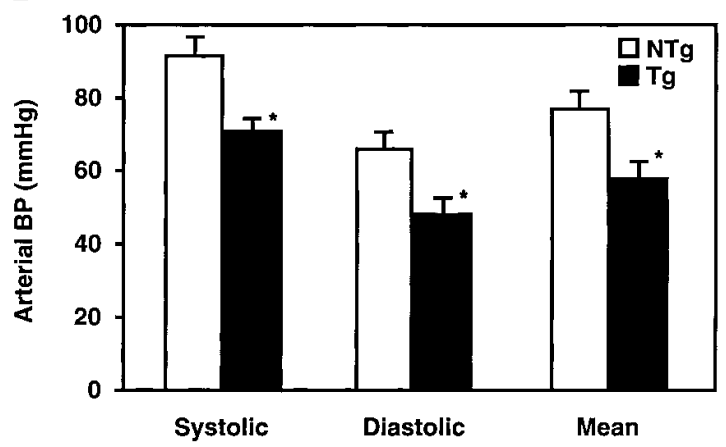

Figure 5. Hemodynamic analyses of the $\mathrm{CREB}_{\mathrm{A} 133}$ mice. $(A)$ Highfidelity left ventricular pressure tracings from control $(N T g)$ and $\mathrm{CREB}_{\mathrm{A} 133}$ transgenic $(T g)$ mice. The solid lines denote $\mathrm{LV}$ pressure, the dotted lines represent the first derivative of pressure $(d P / d t)$. Note the reductions in both peak systolic pressure and maximum $\mathrm{dP} / \mathrm{dt}$ and the decreased minimum $\mathrm{dP} / \mathrm{dt}$ in the $\mathrm{CREB}_{\mathrm{A} 133}$ animal. $(B)$ and $(C)$ mean maximum and minimum $\mathrm{dP} / \mathrm{dt}$ in $\operatorname{CREB}_{\mathrm{A} 133}(T g)(n=$ $10)$ and nontransgenic control littermates $(N T g)(n=10)$ was measured both at baseline $(B)$ and after treatment with a single intravenous bolus of $40 \mathrm{ng} / \mathrm{kg}$ isoproterenol $(I)$. (D) Baseline arterial blood pressures were measured using a micromanometer catheter inserted into the central aorta via the right common carotid artery. The data is shown as mean \pm sem. * and denote significant differences $(P<0.05$ and $P<0.005$, respectively) between the control and Tg groups.

(ANF) gene (42-44) and the $\beta$-MHC gene (45-47). To determine if these molecular markers of increased workload were expressed in the $\mathrm{CREB}_{\mathrm{A} 133}$ hearts, we performed Northern blot analyses with ANF and $\beta$-MHC specific probes (Fig. 6).
A

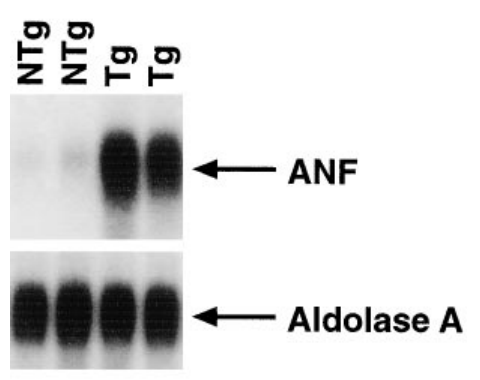

B

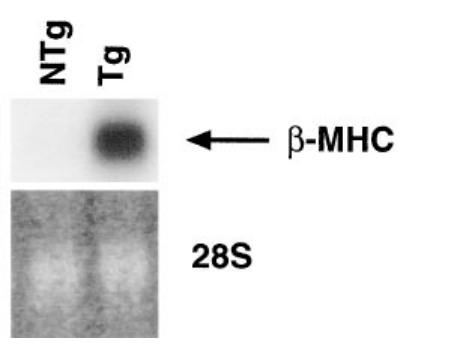

Figure 6. ANF and $\beta$-MHC expression in the $\mathrm{CREB}_{\mathrm{A} 133}$ hearts. $(A)$ Northern blot analysis of ANF expression in two nontransgenic $(N T g)$ and two $\mathrm{CREB}_{\mathrm{A} 133}$ $(T g)$ hearts. Equal loading was shown by rehybridizing the same RNA samples to an aldolase A-specific probe. (B) Northern blot analysis of $\beta$-MHC expression in nontransgenic $(N T g)$ and $\mathrm{CREB}_{\mathrm{A} 133}(T g)$ hearts. Equal loading was shown by quantitation of the 28S RNA (28S).

Hearts from 21-wk-old $\mathrm{CREB}_{\mathrm{A} 133}$ mice demonstrated signficantly increased expression of both ANF and $\beta$-MHC mRNA as compared to hearts from age-matched nontransgenic littermates. Similar up-regulation of ANF and $\beta$-MHC expression was seen in 8-wk-old $\mathrm{CREB}_{\mathrm{A} 133}$ hearts (data not shown).

Apoptosis and contractile protein expression in the $C R E B_{A 133}$ mice. Apoptosis has recently been postulated to play a role in the progression of congestive heart failure in humans (48-50). Therefore, it was of interest to determine if the dilated cardiomyopathy observed in the $\mathrm{CREB}_{\mathrm{A} 133}$ mice was associated with increased cardiac myocyte apoptosis in these animals. Two assays were used to compare apoptosis in $\mathrm{CREB}_{\mathrm{A} 133}$ and wild-type control hearts. As shown in Fig. $6 \mathrm{~A}$ a DNA laddering assay did not reveal evidence of increased apoptosis in the $\mathrm{CREB}_{\mathrm{A} 133}$ hearts. In control experiments, this same assay did detect increased apoptosis in a mouse model of reperfusion injury (Fig. $7 A$ ). In a second series of experiments, we used a TUNEL assay to compare the numbers of apoptotic cardiac myocytes in $\mathrm{CREB}_{\mathrm{A} 133}$ mice and wild-type littermates. In agreement with the DNA-laddering assay, there was no detectable increase in apoptotic cells in the $\mathrm{CREB}_{\mathrm{A} 133}$ hearts (data not shown). We also considered the possibility that expression of the $\mathrm{CREB}_{\mathrm{A} 133}$ transgene caused abnormalities in contractile protein expression in the transgenic mice. However, as shown in Fig. 7 B, no significant abnormalities in contractile protein expression were detected by SDS-PAGE analysis of ventricular proteins from the $\mathrm{CREB}_{\mathrm{A} 133}$ animals. Consistent with these findings, electron microscopic analyses demonstrated normal sarcomere structure in cardiac myocytes from 8-wk-old $\mathrm{CREB}_{\mathrm{A} 133}$ animals (data not shown).

Clinical course of congestive heart failure in the $C R E B_{A 133}$ mice. Congestive heart failure in patients with IDC is a wellcharacterized clinical entity that results in significant morbidity and 5-yr mortality rates as high as $50 \%(1,51-54)$. Patients 
A

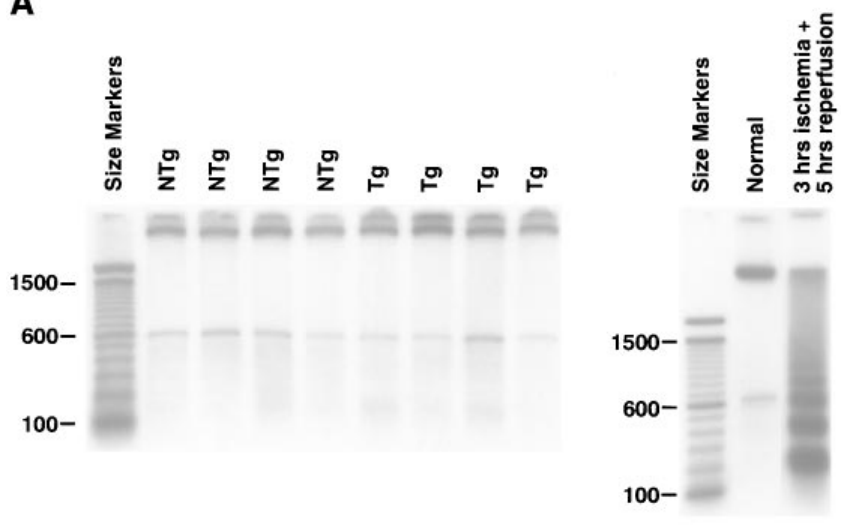

B

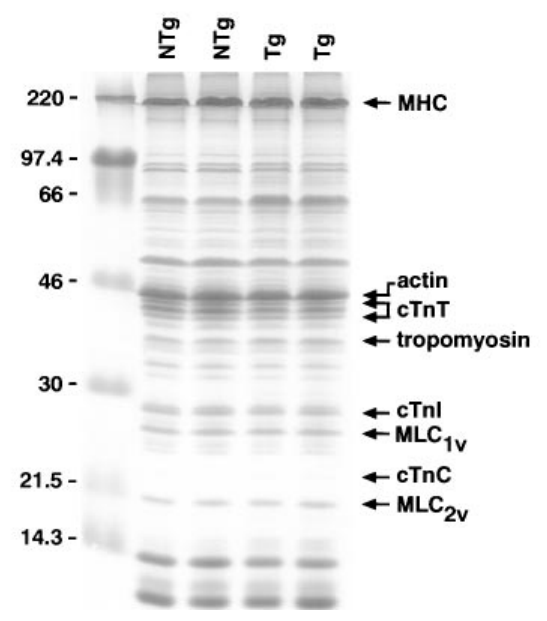

Figure 7. Apoptosis and contractile protein expression in the CREB $_{\mathrm{A} 133}$ hearts. (A) DNA laddering assay. DNA extracted from $\mathrm{CREB}_{\mathrm{A} 133}(T g)$ or control $(N T g)$ hearts was radiolabeled with ${ }^{32} \mathrm{P}-$ $\mathrm{dCTP}$ and dGTP using the Klenow fragment of DNA polymerase I and fractionated by electrophoresis in a $2 \%$ agarose gel (left). In a parallel control experiment a mouse heart was subjected to $3 \mathrm{~h}$ of ischemia and $5 \mathrm{~h}$ of reperfusion by ligation of the left anterior descending artery and a DNA laddering assay was performed (right). Size markers in base pairs are shown to the left of the gel. Note the lack of low molecular weight DNA laddering in both the Tg and NTg hearts as compared to the heart subjected to ischemia and reperfusion. (B) SDS-PAGE analysis of contractile protein expression in $\mathrm{CREB}_{\mathrm{A} 133}(T g)$ and Control $(N T g)$ hearts. Ventricular protein extracts were fractionated by SDS-PAGE and the resulting gel was stained with Coomassie blue. Size markers in kilodaltons are shown to the left of the gel. The positions of individual contractile proteins are shown to the right of the gel.

with end-stage CHF often suffer from both "forward failure" due to reduced cardiac output and perfusion of the vital organs and "backward failure" due to increased pulmonary and systemic venous pressures. Forward failure is often manifest by lethargy, weakness, and confusion while backward failure presents as dyspnea, peripheral edema, hepatic congestion, and ascites. Between 8 and $20 \mathrm{wk}$ of age, the $\mathrm{CREB}_{\mathrm{A} 133}$ mice were noted to develop severe peripheral edema and ascites and to become dyspneic and lethargic, often not moving from one corner of their cages (Fig. $8 \mathrm{~A}$ ). Pathological examination revealed signs of advanced chronic hepatic congestion. Livers from the $\mathrm{CREB}_{\mathrm{A} 133}$ animals demonstrated a classical "nutmeg" appearance with dark red areas of central venous congestion and central lobular necrosis seen by histological analyses (Fig. 8, $B-F$ ). The $\mathrm{CREB}_{\mathrm{A} 133}$ mice also demonstrated significantly increased mortality rates (Fig. 9). Genotypic analyses performed at $2 \mathrm{wk}$ of age revealed equivalent numbers of transgenic and nontransgenic pups suggesting that there were not significant differences in the viabilities of young $\mathrm{CREB}_{\mathrm{A} 133}$ and nontransgenic control littermates. In contrast, between 2 and $20 \mathrm{wk}$ of age the $\mathrm{CREB}_{\mathrm{A} 133}$ animals displayed significantly increased mortality rates as compared with the nontransgenic control mice: $>40 \%$ of the $\mathrm{CREB}_{\mathrm{A} 133}$ animals died by $20 \mathrm{wk}$, whereas $100 \%$ of the nontransgenic control littermates remained alive and healthy $(P<0.000005)$ (Fig. 9).

\section{Discussion}

The $\mathrm{CREB}_{\mathrm{A} 133}$ mice described in this report represent a mouse model of inherited dilated cardiomyopathy that closely resembles the pathologic, hemodynamic, and clinical features of the human disease. Like humans with IDC, these mice displayed progressive four chamber cardiac dilatation, interstitial cardiac fibrosis with myocyte heterogeneity and vacuolization, intracardiac thrombi, and signs of severe chronic venous congestion. They also demonstrated significantly depressed LV systolic function and abnormal diastolic relaxation. Finally, like patients with IDC they displayed significantly increased mortality rates. Taken together, our results identify CREB as a novel and critical transcriptional regulator of cardiac myocyte function and suggest that the $\mathrm{CREB}_{\mathrm{A} 133}$ mice should be a useful animal model for studies of both the pathogenesis and treatment of IDC.

Several previously described genetically modified mice have been reported to develop cardiomyopathies. These include mice expressing mutant forms of $\alpha-\mathrm{MHC}$, mice engineered to ectopically express the myf5 bHLH transcription factor in the heart, and mice containing targeted mutations of the muscle LIM protein (MLP) (55-57). However, the phenotypes of each of these mice differs significantly from that of the $\mathrm{CREB}_{\mathrm{A} 133}$ mice described in this report. Unlike the $\mathrm{CREB}_{\mathrm{A} 133}$ mice which display progressive cardiac dilatation without hypertrophy, the $\alpha$-MHC and myf5 mice develop a hypertrophic cardiomyopathy with myocyte disarray and interstitial fibrosis $(56,57)$. Consistent with these histological findings, the $\alpha$-MHC mice display normal end systolic $\mathrm{LV}$ pressures and $\mathrm{dP} / \mathrm{dt}_{\max }$ but abnormal LV relaxation. These findings are highly reminiscent of the phenotype of patients with hypertrophic as opposed to dilated cardiomyopathy. The phenotype of the $\mathrm{CREB}_{\mathrm{A} 133}$ mice also differed signficantly from that of the recently described muscle LIM protein (MLP)-deficient mice which display soft, markedly hypertrophic hearts with grossly abnormal sarcomere structure within the first several weeks after birth (55). Unlike the mCREB mice, $50-70 \%$ of the MLPdeficient mice die before $10 \mathrm{~d}$ of age.

Mechanism of dilated cardiomyopathy in the CREB $B_{A 133}$ mice. Our findings raise two important questions concerning the mechanism by which overexpression of $\mathrm{CREB}_{\mathrm{A} 133}$ causes dilated cardiomyopathy (DC) in the $\mathrm{CREB}_{\mathrm{A} 133}$ mice. First, what is the mechanism by which the $\mathrm{CREB}_{\mathrm{A} 133}$ protein functions as a dominant-negative transcription factor in these 


\section{NTg $\quad \mathrm{Tg}$}
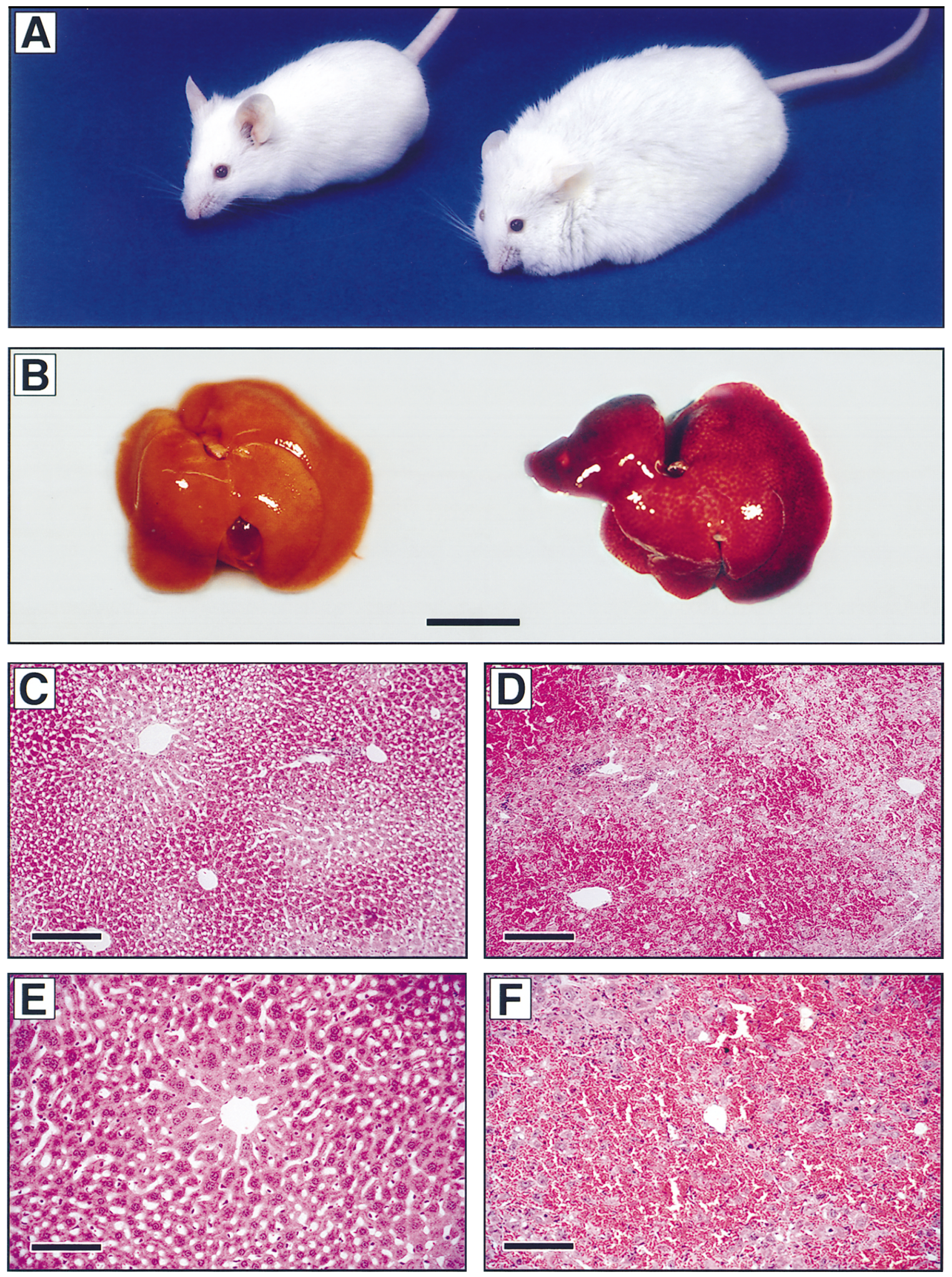

Figure 8. Signs of congestive heart failure in the $\mathrm{CREB}_{\mathrm{A} 133}$ mice. $(A)$ Photographs of a 20 -wk-old $\mathrm{CREB}_{\mathrm{A} 133}$ mouse (right) and a nontransgenic littermate (left). Note the massive generalized edema in the $\mathrm{CREB}_{\mathrm{A} 133}$ mouse. $(B)$ Gross pathology of freshly isolated livers from a $\mathrm{CREB}_{\mathrm{A} 133}$ mouse (right) and a nontransgenic littermate (left). Note the nutmeg appearance of the $\mathrm{CREB}_{\mathrm{A} 133}$ liver. Size bar, $10 \mathrm{~mm}$. $(C-F)$ Photomicrographs of histological sections of livers obtained from $\operatorname{CREB}_{\mathrm{A} 133}(D$ and $F)$ and nontransgenic control littermates $(C$ and $E)$. Note the central venous congestion (bright red staining) and the central lobular hepatocyte necrosis in the $\mathrm{CREB}_{\mathrm{A} 133}$ livers. Size bars, $200 \mu \mathrm{m}(C$ and $D)$ and 100 $\mu \mathrm{m}(E$ and $F)$. 


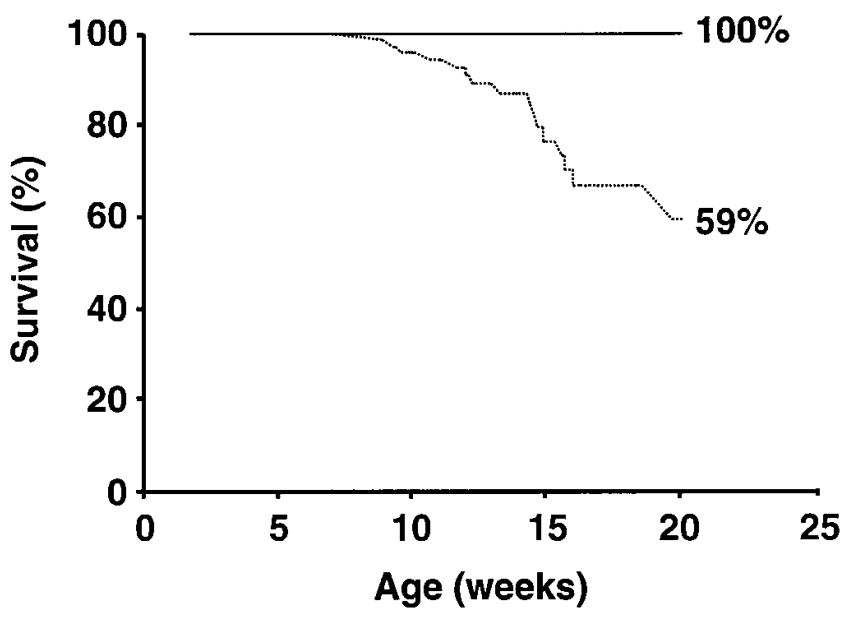

Figure 9. Kaplan-Meier survival analysis of the $\mathrm{CREB}_{\mathrm{A} 133}$ mice. The solid line shows the Kaplan-Meier estimate of the survivor functions of the nontransgenic control littermates. The dotted line shows the Kaplan-Meier estimate of the survivor functions of the $\mathrm{CREB}_{\mathrm{A} 133}$ mice. The fraction of mice surviving in each group at the end of $20 \mathrm{wk}$ is noted at the right of the plot. Both groups started with 72 mice. Differences in survival rates between the Tg and NTg groups were significant by the $\log$ rank test $(P<0.000005)$.

mice? And secondly, what are the target genes that are dysregulated by overexpression of $\mathrm{CREB}_{\mathrm{A} 133}$ in cardiac myocytes? There are at least three different molecular mechanisms by which overexpression of $\mathrm{CREB}_{\mathrm{A} 133}$ could dysregulate $\mathrm{CREB}$ dependent transcription. First, because $\mathrm{CREB}_{\mathrm{A} 133}$ can bind to DNA but fails to activate transcription, it has been shown to displace transcriptionally active CREB from CRE sites and to thereby down-regulate CREB-dependent transcription (22, 23). Our EMSA data showing that the majority of the CREBbinding activity in $\mathrm{CREB}_{\mathrm{A} 133}$ nuclear extracts represents $\mathrm{CREB}_{\mathrm{A} 133}$-containing dimers suggests that this mechanism may account for at least some of the dominant-negative effects of the transgene. Secondly, our finding of decreased phosphoCREB in the $\mathrm{CREB}_{\mathrm{A} 133}$ cardiac nuclear extracts suggests that the $\mathrm{CREB}_{\mathrm{A} 133}$ protein may displace wild-type CREB from the appropriate $\mathrm{CREB}$ kinases. $\mathrm{CREB}_{\mathrm{A} 133}$ can dimerize with wildtype CREB as well as with other selected members of the CREB/ATF family (12). Thus, overexpresion of $\mathrm{CREB}_{\mathrm{A} 133}$ might also squelch CREB/ATF-dependent transcription by altering the balance of different CREB/ATF dimers present in the cell. This mechanism seems somewhat less likely given the fact that CREB homodimers appear to be the predominant CRE binding activity in normal cardiac myocytes and that we failed to detect novel CRE or AP-1-binding complexes in the $\mathrm{CREB}_{\mathrm{A} 133}$ nuclear extracts. Finally, it is possible that $\mathrm{CREB}_{\mathrm{A} 133}$ functions as a dominant-negative transcription factor by interacting with other (non-CREB/ATF) members of the transcriptional machinery. To some extent, it may be possible to determine the relative importance of these different mechanisms by producing transgenic mice that overexpress mutant forms of the CREB protein that specifically lack kinase binding, DNA binding, or dimerization activities in the heart and comparing their phenotypes to those of the $\mathrm{CREB}_{\mathrm{A} 133}$ animals. Regardless of its mechanism of dominant-negative action, it should be emphasized that the dilated cardiomyopathic phenotype of the $\mathrm{CREB}_{\mathrm{A} 133}$ mice is specific and not simply an artifact reflecting overexpression of a protein from the $\alpha$-MHC promoter because transgenic mice overexpressing comparable or greater levels of $\beta$-galactosidase, Bcl-x, or slow skeletal TnI from the same promoter do not develop cardiomyopathy (Fentzke, R., and J. Leiden, data not shown).

What is the mechanism underlying the IDC observed in the $\mathrm{CREB}_{\mathrm{A} 133}$ mice? It is logical to postulate that CREB normally regulates the transcription of target genes that are required for the function and/or survival of cardiac myocytes and that expression of the $\mathrm{CREB}_{\mathrm{A} 133}$ transgene product results in the dysregulated expression of these CREB target genes. Such CREB target genes might encode a wide variety of proteins including contractile proteins, proteins involved in generating energy or regulating excitation-contraction coupling and/or proteins required for cardiac myocyte growth or viability. Our studies did not reveal significant differences in contractile protein expression, or apoptosis in the $\mathrm{CREB}_{\mathrm{A} 133}$ hearts. However, it should be emphasized that low levels of cardiomyocyte apoptosis and/ or very early apoptosis which might not have been detected by our TUNEL assays could account for the DC seen in these animals. Nevertheless, our findings suggest that CREB may regulate the expression of other genes involved in cardiac myocyte growth, function and/or viability. The identification of these CREB target genes using differential display approaches will represent an important next step in understanding the physiological function of the CREB transcription pathway in the heart.

The CREB pathway and human dilated cardiomyopathy. Our finding of $\mathrm{DC}$ in the $\mathrm{CREB}_{\mathrm{A} 133}$ mice raises the possibility that CREB may be involved in the etiology of human dilated cardiomyopathy. It has been estimated that at least $20 \%$ of IDC is inherited in an autosomal dominant fashion (58). Loci for inherited IDC have recently been identified on human chromosomes 1p1-1q1, 1q32, 3p22-p25 and 9 (6, 59-61). Because CREB maps to human chromosome 2q32.3-34 (62), it is unlikely that mutations in the CREB gene are directly responsible for the inherited dilated cardiomyopathies seen in these families. Nevertheless, our finding of inherited DC in the $\mathrm{CREB}_{\mathrm{A} 133}$ mice directly implicates CREB as a member of a transcriptional pathway that plays a critical role in regulating cardiac myocyte function. Mutations in the genes encoding the proteins of this pathway are logical candidates for inherited DC. It will therefore be of interest to determine both the signaling pathways that regulate CREB activity in cardiac myocytes as well as the down-stream targets of CREB in these cells.

CREB may also play a secondary role in the progression of $\mathrm{CHF}$ in patients with dilated cardiomyopathy resulting from a wide range of primary etiologies. Previous studies have demonstrated that CREB mRNA levels are down-regulated following chronic $\beta$-adrenergic stimulation in the rat (26). Chronic $\beta$-adrenergic stimulation has also been proposed to play a major role in the progression of human heart failure (30-32). When taken together with our results, these findings suggest a model in which chronic $\beta$-adrenergic stimulation leads to CREB down-regulation, a situation that would mimic that observed in the $\mathrm{CREB}_{\mathrm{A} 133}$ mice, and which might, therefore, lead to progressive cardiac dysfunction. If correct, this model suggests that therapies designed to increase CREB activity in the failing heart might slow the progression of CHF. It is also consistent with the previously observed adverse effects 
of $\beta$-adrenergic agonist therapy $(63,64)$ and the beneficial effects of treatment with $\beta$-blockers in patients with $\mathrm{CHF}(53,65)$.

The lack of a reproducible animal model of IDC has limited our ability to understand the molecular basis of IDC, to study the early physiological changes that contribute to the progression of the disease, and to develop and test therapies for this clinically important disorder. Thus, in addition to providing us with important basic information concerning the role of the CREB transcriptional pathway in regulating cardiac myocyte function, the $\mathrm{CREB}_{\mathrm{A} 133}$ mice will also allow us to address important pathophysiological and clinical questions about IDC. The relatively rapid clinical course of CHF in these animals will facilitate studies designed to identify new drugs that can decrease the morbidity and mortality associated with the disease. In addition, we can conveniently test the effects of other interventions such as exercise and diet, both of which remain controversial in human IDC. It is now possible to obtain electrocardiograms in conscious, resting $\mathrm{CREB}_{\mathrm{A} 133}$ mice to assess the role of cardiac arrhythmias in the early mortality observed in these animals and to test the feasibility of using antiarrhythmic drugs to modify mortality rates. By breeding the $\mathrm{CREB}_{\mathrm{A} 133}$ mice with other transgenic and knock-out mice we can test the ability of candidate genes to modify the hemodynamic and clinical abnormalities seen in these animals. Finally, it may be possible to use positional cloning to identify genes that can modify (both positively and negatively) the severity of $\mathrm{CHF}$ in the $\mathrm{CREB}_{\mathrm{A} 133}$ mice.

\section{Acknowledgments}

We thank K. Sigrist and C. Clendenin for help with the preparation of transgenic mice, L. Gottschalk for help with the preparation of illustrations, and P. Lawrey for assistance with preparation of the manuscript. We thank M. Parmacek for his critical review of the manuscript and $\mathrm{M}$. Chen for help with statistical analyses.

This work was supported in part by National Heart Lung and Blood Institute grant HL54592 (to J.M. Leiden).

\section{References}

1. Cohn, J.N. 1996. The management of chronic heart failure. N. Engl. J. Med. 335:490-498.

2. Massie, B.M., and M. Packer. 1990. Congestive heart failure: current controversies and future prospects. Am. J. Cardiol. 66:429-430.

3. Davies, M.J., and W.J. McKenna. 1994. Dilated cardiomyopathy: an introduction to pathology and pathogenesis. Br. Heart J. 72(Suppl.):S24.

4. Dec, G.W., and V. Fuster. 1994. Idiopathic dilated cardiomyopathy. $N$. Engl. J. Med. 331:1564-1575.

5. McMinn, T.R., and J. Ross. 1995. Hereditary dilated cardiomyopathy. Clin. Cardiol. 18:7-15.

6. Durand, J.-B., A.B. Abchee, and R. Roberts. 1995. Molecular and Clinical Aspects of Inherited Cardiomyopathies. Ann. Med. 27:311-317.

7. Codd, M.B., D.D. Sugrue, B.J. Gersh, and I.L.J. Melton. 1989. Epidemiology of idiopathic dilated and hypertrophic cardiomyopathy: a populationbased study in Olmsted County, Minnesota. Circulation. 80:564-572.

8. Montminy, M.R., and L.M. Bilezikjian. 1987. Binding of a nuclear protein to the cyclic-AMP response element of the somatostatin gene. Nature. 328: $175-178$

9. Gonzalez, G.A., K.K. Yamamoto, W.H. Fischer, D. Karr, P. Menzel, I.W. Biggs, W.W. Vale, and M.R. Montminy. 1989. A cluster of phosphorylation sites on the cyclic AMP-regulated nuclear factor CREB predicted by its sequence. Nature. 337:749-752.

10. Habener, J.F. 1990. Cyclic AMP response element binding proteins: a cornucopia of transcription factors. [review]. Mol. Endocrinol. 4:1087-1094.

11. Hoeffler, J.P., T.E. Meyer, Y. Yun, J.L. Jameson, and J.F. Habener. 1988. Cyclic AMP-responsive DNA-binding protein: structure based on a cloned placental cDNA. Science. 242:1430-1433.

12. Vallejo, M. 1994. Transcriptional control of gene expression by cAMPresponse element binding proteins. J. Neuroendocrinol. 6:587-596.
13. Ginty, D.D., A. Bonni, and M.E. Greenberg. 1994. Nerve growth factor activates a Ras-dependent protein kinase that stimulates c-fos transcription via phosphorylation of CREB. Cell. 77:713-725.

14. Barton, K., N. Muthusamy, M. Chanyangam, C. Fischer, C. Clendenin, and J.M. Leiden. 1996. Defective thymocyte proliferation and IL-2 production in transgenic mice expressing a dominant-negative form of CREB. Nature. 379: 81-85.

15. Gonzalez, G.A., and M.R. Montminy. 1989. Cyclic AMP stimulates somatostatin gene transcription by phosphorylation of CREB at Serine 133. Cell. 59:675-680.

16. Yamamoto, K.K., G.A. Gonzalez, I.W.H. Biggs, and M.R. Montminy. 1988. Phosphorylation-induced binding and transcriptional efficacy of nuclear factor CREB. Nature. 334:494-498.

17. Kwok, R.P., J.R. Lundblad, J.C. Chrivia, J.P. Richards, H.P. Bachinger, R.G. Brennan, S.G. Roberts, M.R. Green, and R.H. Goodman. 1994. Nuclear protein CBP is a coactivator for the transcription factor CREB. Nature. 370: 223-226.

18. Arias, J., A.S. Alberts, P. Brindle, F.X. Claret, T. Smeal, M. Karin, J. Feramisco, and M. Montminy. 1994. Activation of cAMP and mitogen responsive genes relies on a common nuclear factor. Nature. 370:226-229.

19. Chrivia, J.C., R.P. Kwok, N. Lamb, M. Hagiwara, M.R. Montminy, and R.H. Goodman. 1993. Phosphorylated CREB binds specifically to the nuclear protein CBP. Nature. 365:855-859.

20. Sheng, M., M.A. Thompson, and M.E. Greenberg. 1991. CREB: a $\mathrm{Ca} 2+$-regulated transcription factor phosphorylated by calmodulin-dependent kinases. Science. 252:1427-1430.

21. Xing, J., D.D. Ginty, and M.E. Greenberg. 1996. Coupling of the RASMAPK pathway to gene activation by RSK2, a growth factor-regulated CREB kinase. Science. 273:959-962

22. Ofir, R., V.J. Dwarki, D. Rashid, and I.M. Verma. 1991. CREB represses transcription of fos promoter: role of phosphorylation. Gene Exp. 1:55-60.

23. Lamph, W.W., V.J. Dwarki, R. Ofir, M. Montminy, and I.M. Verma. 1990. Negative and positive regulation by transcription factor cAMP response element-binding protein is modulated by phosphorylation. Proc. Natl. Acad. Sci. USA. 87:4320-4324.

24. Struthers, R.S., W.W. Vale, C. Arias, P.E. Sawchenko, and M.R. Montminy. 1991. Somatotroph hypoplasia and dwarfism in transgenic mice expressing a non-phosphorylatable CREB mutant. Nature. 350:622-624.

25. Goldspink, P.H., and B. Russell. 1994. The cAMP response element binding protein is expressed and phosphorylated in cardiac myocytes. Circ. Res. 74:1042-1049.

26. Muller, F.U., P. Boknik, A. Horst, J. Knapp, B. Linck, W. Schmitz, U. Vahlensieck, and A. Walter. 1995. In vivo isoproterenol treatment leads to downregulation of the mRNA encoding the cAMP response element binding protein in the rat heart. Biochem. Biophys. Res. Commun. 215:1043-1049.

27. Muller, F.U., P. Boknik, A. Horst, J. Knapp, B. Linck, W. Schmitz, U. Vahlensieck, M. Bohm, M.C. Deng, and H.H. Scheld. 1995. cAMP response element binding protein is expressed and phosphorylated in human heart. Circulation. 92:2041-2043.

28. Milano, C.A., L.F. Allen, H.A. Rockman, P.C. Dolber, T.R. McMinn, K.R. Chien, T.D. Johnson, R.A. Bond, and R.J. Lefkowitz. 1994. Enhanced myocardial function in transgenic mice overexpressing the Beta2-adrenergic receptor. Science. 264:582-586.

29. Koch, W.J., H.A. Rockman, P. Samama, R. Hamilton, R.A. Bond, C.A. Milano, and R.J. Lefkowitz. 1995. Cardiac function in mice overexpressing the beta-adrenergic receptor kinase or a BetaARK inhibitor. Science. 268:1350 1353.

30. Bristow, M.R., R. Ginsburg, W. Minobe, R.S. Cubicciotti, W.S. Sageman, K. Lurie, M.E. Billingham, D.C. Harrison, and E.B. Stinson. 1982. Decreased catecholamine sensitivity and beta-adrenergic-receptor density in failing human hearts. N. Engl. J. Med. 307:205-211.

31. Bristow, M.R., N.E. Kantrowitz, R. Ginsburg, and M.B. Fowler. 1985. Beta-adrenergic function in heart muscle disease and heart failure. [review]. $J$. Mol. Cell. Cardiol. 17(Suppl. 2):41-52.

32. Bristow, M.R., R.E. Hershberger, J.D. Port, E.M. Gilbert, A. Sandoval, R. Rasmussen, A.E. Cates, and A.M. Feldman. 1990. Beta-adrenergic pathways in nonfailing and failing human ventricular myocardium. Circulation. 82(Suppl.):I12-I25.

33. Subramaniam, A., W.K. Jones, J. Gulick, S. Wert, J. Neumann, and J. Robbins. 1991. Tissue-specific regulation of the alpha-myosin heavy chain gene promoter in transgenic mice. J. Biol. Chem. 266:24613-24620.

34. Gulick, J., A. Subramaniam, J. Neumann, and J. Robbins. 1991. Isolation and characterization of the mouse cardiac myosin heavy chain genes. $J$. Biol. Chem. 266:9180-9185.

35. Palermo, J., J. Gulick, W. Ng, I.L. Grupp, G. Grupp, and J. Robbins. 1995. Remodeling the mammalian heart using transgenesis. Cell. Mol. Biol. Res. 41:501-509.

36. Palermo, J., J. Gulick, M. Colbert, J. Fewell, and J. Robbins. 1996 Transgenic remodeling of the contractile apparatus in the mammalian heart. Circ. Res. 78:504-509.

37. Fentzke, R.C., C.E. Korcarz, S.G. Shroff, H. Lin, J. Sandelski, J.M. Leiden, and R.M. Lang. 1997. Evaluation of ventricular and arterial hemody- 
namics in anesthetized closed-chest mice.J. Am. Soc. Echocardiogr. 10:915-925.

38. Manning, W.J., J.Y. Wei, S.E. Katz, P.S. Douglas, and J.K. Gwathmey. 1993. Echocardiographically detected myocardial infarction in the mouse. Lab. Anim. Sci. 43:583-585.

39. Hoit, B.D., S.F. Khoury, E.G. Kranias, N. Ball, and R.A. Walsh. 1995. In vivo echocardiographic detection of enhanced left ventricular function in gene-targeted mice with phospholamban deficiency. Circ. Res. 77:632-637.

40. Gardin, J.M., F.M. Siri, R.N. Kitsis, J.G. Edwards, and L.A. Leinwand. 1995. Echocardiographic assessment of left ventricular mass and systolic function in mice. Circ. Res. 76:907-914.

41. Pollick, C., S.L. Hale, and R.A. Kloner. 1995. Echocardiographic and cardiac Doppler assessment of mice. J. Am. Soc. Echocardiogr. 602-610.

42. Edwards, B.S., D.M. Ackermann, M.E. Lee, G.S. Reeder, L.E. Wold, and J.C. Burnett, Jr. 1988. Identification of atrial natriuretic factor within ventricular tissue in hamsters and humans with congestive heart failure. J. Clin. Invest. 81:82-86.

43. Lattion, A.L., J.B. Michel, E. Arnauld, P. Corvol, and F. Soubrier. 1986. Myocardial recruitment during ANF mRNA increase with volume overload in the rat. Am. J. Physiol. 251 (5 Pt 2):H890-H896.

44. Izumo, S., B. Nadal-Ginard, and V. Mahdavi. 1988. Protooncogene induction and reprogramming of cardiac gene expression produced by pressure overload. Proc. Natl. Acad. Sci. USA. 85:339-343.

45. Lompre, A.M., K. Schwartz, A. d'Albis, G. Lacombe, N. Van Thiem, and B. Swynghedauw. 1979. Myosin isoenzyme redistribution in chronic heart overload. Nature. 282:105-107.

46. Izumo, S., A.M. Lompre, R. Matsuoka, G. Koren, K. Schwartz, B. Nadal-Ginard, and V. Mahdavi. 1987. Myosin heavy chain messenger RNA and protein isoform transitions during cardiac hypertrophy. Interaction between hemodynamic and thyroid hormone-induced signals. J. Clin. Invest. 79:970-977.

47. Mercadier, J.J., A.M. Lompre, C. Wisnewsky, J.L. Samuel, J. Bercovici, B. Swynghedauw, and K. Schwartz. 1981. Myosin isoenzyme changes in several models of rat cardiac hypertrophy. Circ. Res. 49:525-532.

48. Narula, J., N. Haider, R. Virmani, T.G. DiSalvo, F. Kolodgie, R.J. Hajjar, U. Schmidt, M.J. Semigran, G.W. Dec, and B. Khaw. 1996. Apoptosis in myocytes in end-stage heart failure. N. Engl. J. Med. 335:1182-1189.

49. Yao, M., A. Keogh, P. Spratt, C.G. dos Remedios, and P.C. Kiebling. 1996. Elevated DNase 1 levels in human idiopathic dilated cardiomyopathy: an indicator of apoptosis? J. Mol. Cell. Cardiol. 28:95-101.

50. Sharov, V.G., H.N. Sabbah, H. Shimoyama, A.V. Goussev, M. Lesch, and S. Goldstein. 1996. Evidence of cardiocyte apoptosis in myocardium of dogs with chronic heart failure. Am. J. Pathol. 148:141-149.

51. Group, C.T. 1987. Effects of enalapril on mortality in severe congestive heart failure: Results of the Cooperative North Scandinavian Enalapril Survival Study. N. Engl. J. Med. 316:1429-1435.

52. Cohn, J.N., D.Z. Archibald, S. Ziesche, J.A. Franciosa, W.E. Harston, F.E. Tristani, W.B. Dunkman, W. Jacobs, G.S. Francis, and K.H. Flohr. 1986.
Effect of vasodilator therapy on mortality in chronic congestive heart failure: Results of a Veterans Administration Cooperative Study (V-HeFT). N. Engl. J. Med. 314:1547-1552.

53. SOLVD Investigators. 1991. Effect of enalapril on survival in patients with reduced left ventricular ejection fractions and congestive heart failure. $N$. Engl. J. Med. 325:293-302.

54. Pfeffer, M.A., E. Braunwald, L.A. Moye, L. Basta, J.E.J. Brown, T.E. Cuddy, B.R. Davis, E.M. Geltman, S. Goldman, and G.C. Flaker. 1992. Effect of captopril on mortality and morbidity in patients with left ventricular dysfunction after myocardial infarction. Results of the survival and ventricular enlargement trial. N. Engl. J. Med. 327:669-677.

55. Arber, S., J.J. Hunter, J. Ross, Jr., M. Hongo, G. Sansig, J. Borg, J.C Perriard, K.R. Chien, and P. Caroni. 1997. MLP-deficient mice exhibit a disruption of cardiac cytoarchitectural organization, dilated cardiomyopathy, and heart failure. Cell. 88:393-403.

56. Edwards, J.G., G.E. Lyons, B.K. Micales, A. Malhotra, S. Factor, and L.A. Leinwand. 1996. Cardiomyopathy in transgenic myf5 mice. Circ. Res. 78 379-387.

57. Geisterfer-Lowrance, A.A., M. Christe, D.A. Conner, J.S. Ingwall, F.J. Schoen, C.E. Seidman, and J.G. Seidman. 1996. A. mouse model of familial hypertrophic cardiomyopathy. Science. 272:731-734.

58. Michels, V.V., P.P. Moll, F.A. Miller, J. Tajik, J. Chu, D.J. Driscoll, J.C. Burnett, F.J. Rodeheffer, J.H. Chesebro, and H.D. Tazelaar. 1992. The frequency of familial dilated cardiomyopathy in a series of patients with idiopathic dilated cardiomyopathy. N. Engl. J. Med. 326:77-81.

59. Kass, S., C. MacRae, H.L. Graber, E.A. Sparks, D. McNamara, H. Boudoulas, C.T. Basson, I.P.B. Baker, R.J. Cody, and M.C. Fishman. 1994. A gene defect that causes conduction system disease and dilated cardiomyopathy maps to chromosome 1p1-1q1. Nat. Genet. 7:546-551.

60. Krajinovic, M., B. Pinamonti, G. Sinagra, M. Vatta, G.M. Severini, J. Milasin, A. Falaschi, F. Camerini, M. Giacca, and L. Mestroni. 1995. Linkage of familial dilated cardiomyopathy to chromosome 9. Heart Muscle Disease Study Group. Am. J. Hum. Genet. 57:846-852.

61. Olson, T.M., and M.T. Keating. 1996. Mapping a cardiomyopathy locus to chromosome 3p22-p25. J. Clin. Invest. 97:528-532.

62. Taylor, A.K., I. Klisak, T. Mohandas, R.S. Sparkes, C. Li, R. Gaynor, and A.J. Lusis. 1990. Assignment of the human gene for CREB1 to chromosome 2q32.3-q34. Genomics. 7:416-421.

63. Lerer, C.V. 1992. Current status of non-digitalis positive inotropic drugs. Am. J. Cardiol. 69:120G-128G.

64. Packer, M., J.R. Carver, R.J. Roceheffer, and P.S.R. Group. 1991. Effect of oral milrinone on mortality in severe chronic heart failure. N. Engl. J. Med. 325:1468-1475.

65. Waagstein, F., M.R. Bristow, and K. Swedberg. 1993. Beneficial effects of metroprolol in idiopathic dilated cardiomyopathy: a double-blind, randomized, placebo-controlled trial. Circulation. 342:1441-1446. 